\title{
PENGARUH CUSTOMER EXPERIENCE TERHADAP CUSTOMER SATISFACTION PADA PASIEN RAWAT INAP KELAS VIP DI RUMAH SAKIT IMMANUEL BANDUNG
}

\author{
NOVITA WULANSARI YUNUS1, AGUS ARIBOWO2 \\ Universitas Kristen Maranatha ${ }^{12}$ \\ e-mail : novi_yunus@yahoo.com
}

\begin{abstract}
The purpose of this study was to determine the effect of customer experience on customer satisfaction in VIP class inpatients at Immanuel Hospital Bandung. Customer experience is measured through the dimensions of environment, convenience, competence, helpfulness. Customer satisfaction is measured through the dimensions of performance, reliability, and service ability. The method used in this research is descriptive method with quantitative and qualitative approaches. Descriptive method aims to provide an overview of the object of research based on the facts collected. The population is the patient and the patient's family at the Immanuel Hospital in Bandung. The sample of this study is inpatient service users of the VIP class Immanuel Hospital in the period of November 2019 - March 2020. In the study sample, researchers used the Slovin formula with a confidence level of $95 \%$ and an error rate of $5 \%$, obtained a total sample of 170 people. Data analysis techniques using the classic assumption test was consisting of normality test, heteroscedasticity test, multicollinearity test, autocorrelation test, partial test (t-test) based on significance value, simultaneous test (F-test) based on the significant value, and coefficient of determination analysis. The results showed a positive effect of customer experience on customer satisfaction in VIP class inpatients at Immanuel Hospital Bandung.
\end{abstract}

Key Words : Customer Experience, Customer Satisfaction, Inpatient

\begin{abstract}
ABSTRAK
Tujuan penelitian adalah untuk mengetahui pengaruh customer experience terhadap customer satisfaction pada pasien rawat inap kelas VIP Di Rumah Sakit Immanuel Bandung. Customer experience diukur melalui dimensi environtment, convenience, competence, helpfulness. Customer satisfaction diukur melalui dimensi performance, realiability, dan service ability. Metode yang digunakan dalam penelitian ini adalah metode deskriptif dengan pendekatan kuantitatif dan kualitatif. Metode deskriptif bertujuan untuk memberikan gambaran dari objek penelitian berdasarkan fakta-fakta yang terkumpul. Populasi adalah pasien dan keluarga pasien di Instalasi Rawat Inap Rumah Sakit Immanuel Bandung. Adapun sampel dari penelitian ini yaitu pengguna jasa rawat inap Rumah Sakit Immanuel kelas VIP periode November 2019 - Maret 2020. Dalam pengambilan sampel penelitian, peneliti menggunakan rumus Slovin dengan tingkat kepercayaan 95\% dan tingkat error 5\%, didapat jumlah sampel sebanyak 170 orang. Teknik analisis data menggunakan uji asumsi klasik yang terdiri dari uji normalitas, uji heteroskedastisitas, uji multikolinearitas, uji autokorekasi, uji parsial (t-test) berdasarkan nilai signifikansi, uji simultan (F-test) berdasarkan nilai signifikansi dan analisis koefisien determinasi. Hasil penelitian menunjukkan adanya pengaruh yang positif customer experience terhadap customer satisfaction pada pasien rawat inap kelas VIP di Rumah Sakit Immanuel Bandung.
\end{abstract}

Kata Kunci: customer experience, customer satisfaction, pasien rawat inap 


\section{PENDAHULUAN}

Saat ini industri jasa layanan kesehatan memasuki era dimana pengalaman konsumen menjadi faktor yang sangat penting untuk mendapatkan keunggulan kompetitif. Meskipun pengalaman konsumen (customer experience) berpengaruh penting terhadap kepuasan konsumen, pengetahuan yang berkaitan dengan hal tersebut masih dirasakan kurang. Dengan semakin banyak didirikannya rumah sakit membuat masyarakat memiliki banyak pilihan rumah sakit yang sesuai dengan kebutuhan atau keinginan. Pertumbuhan jasa layanan kesehatan yang pesat mengakibatkan perusahaan harus menerapkan strategi bersaingnya melalui customer experience quality dengan tujuan untuk meningkatkan reputasi perusahaan yang mengarah kepada keunggulan bersaing (competitive advantage), seperti menarik minat konsumen baru dan mempertahankan konsumen lama. Penelitian ini dilakukan untuk mengetahui pengaruh customer experience terhadap customer satisfaction dan mengidentifikasi unsur-unsur titik kontak customer experience, yaitu titik-titik kritis dimana konsumen merasakan jasa/layanan rumah sakit.

\section{TINJAUAN PUSTAKA}

Pengalaman pelanggan

(customer experience) menurut Shaw \& Ivens [4] adalah interaksi antara organisasi dan pelanggan, yang merupakan campuran dari kinerja fisik organisasi, indera yang dirangsang dan emosi yang ditimbulkan, masing-masing diukur secara intuitif terhadap pengalaman pelanggan di semua momen kontak. Dalam jurnal yang berjudul Understanding Customer Experience Management in Retailing, Erna Andajani [5] menyatakan bahwa pengalaman konsumen adalah seluruh peristiwa yang dialami oleh konsumen dalam proses sebelum dan setelah pembelian. Fokus pada customer experience yang berkualitas menurut Lemke, et.all [6] bertujuan untuk memahami apa yang diinginkan konsumen dimana hal ini mendorong kreativitas perusahaan untuk menciptakan hubungan yang bernilai. Sedangkan Kim, S., Cha, J., Knutson, B. J., \& Beck, J. A [7] dalam jurnalnya "Development and testing of the Consumer Experience Index (CEI): Managing Service Quality" memaparkan 7 dimensi customer experience yang saling berhubungan yaitu lingkungan, manfaat, kenyamanan, aksesibilitas, utilitas, insentif, dan kepercayaan. Sedangkan Lemke et.al [6] mengemukakan 8 faktor paling penting dalam mempengaruhi B2C customer experience yaitu accessibility, competence, customer recognition, helpfulness, personalization, problem solving, promise fulfillment, dan value for time. Bagaimana memberikan pengalaman kepada konsumen menjadi cara untuk membedakan dari pesaing. Pine dan Gilmore[8] menyatakan bahwa pengalaman terjadi ketika suatu perusahaan dengan sengaja menggunakan layanan sebagai tahapan dan produk untuk melibatkan pelanggan dengan cara menciptakan pengalaman yang tak terlupakan. Menurut Alisha Stein [9] pemahaman yang kuat mengenai pengalaman pelanggan akan membantu penyedia layanan untuk secara efektif merancang, memantau, dan menilai pengalaman pelanggan real-time pada touch points individual.

Kepuasan (satisfaction) adalah perasaan senang atau kecewa seseorang yang timbul karena membandingkan kinerja yang dipersepsikan produk (atau hasil) terhadap ekspetasi mereka, jika kinerja gagal memenuhi ekspetasi , konsumen akan tidak puas. Kotler \& Keller [10] menyatakan jika kinerja sesuai dengan ekspetasi, konsumen akan puas. Jika kinerja melebihi ekspetasi , konsumen akan sangat puas dan senang. Ukuran tingkat kepuasan konsumen menurut Susatyo Herlambang [1] adalah pada saat mengukur tingkat perasaan dengan membandingkan kinerja atau hasil yang dirasakan dibandingkan dengan harapannya. Eisenbeiss, Corneliben, Backhaus dan Hoyer [11] menekankan faktor penentu seperti kualitas produk, efisiensi produk, pemulihan layanan, dan cara pelanggan ditangani oleh karyawan dari suatu organisasi, sedangkan Moreson, Forrest, Sharma, Nidhi dan Hult[12] berpendapat faktor komunikasi sebagai faktor penting yang menentukan customer satisfaction. Apabila konsumen dalam hal ini pasien tidak merasakan kepuasan akan layanan kesehatan, rumah sakit tidak akan dapat mempertahankan konsumennya dan konsumen dapat beralih ke rumah sakit competitor. Kepuasan konsumen menurut Kotler dan Keller [10] merupakan kunci yang penting untuk dapat mempertahankan pelanggan karena kepuasan adalah perasaan senang atau kecewa seseorang yang dihasilkan dari membandingkan kinerja (atau hasil) yang dirasakan suatu produk atau layanan dengan harapan. Fandy Tjiptono [2] menyatakan bahwa kepuasan pasien ditentukan oleh beberapa faktor antara lain,yaitu kinerja (performance, ciri-ciri atau keistimewaan tambahan (features), keandalan (reliability), kesesuaian dengan spesifikasi (conformance to spesification), daya tahan (durability), service ability, estetika, kualitas yang dipersepsikan (perceived quality) dan komunikasi. 


\section{METODE}

Penelitian ini bertujuan untuk mengetahui pengaruh customer experience terhadap customer satisfaction pada pasien rawat inap kelas VIP di Rumah Sakit Immanuel Bandung. Metode yang digunakan dalam penelitian ini adalah metode deskriptif dengan pendekatan kuantitatif dan kualitatif. Metode deskriptif bertujuan untuk memberikan gambaran dari objek penelitian berdasarkan fakta-fakta yang terkumpul. Pendekatan kuantitatif dimaksudkan untuk menemukan hubungan sebab akibat antara variabel -variabel dalam penelitian, dimana variabel terikat merupakan akibat variabel bebas dan untuk membuktikan hipotesis. Peneliti menggunakan metode kualitatif dengan tujuan untuk memperkuat, menguji, memperluas, memperdalam, dan menemukan data baru yang tidak dapat diperoleh dengan metode kuantitatif. Teknik pengumpulan data metode kualitatif adalah participant observation dan in depth interview. Sampel sumber data dalam penelitian kualitatif bersifat purposive, dipilih 10 sampel atau responden yang diberikan kuestioner bersifat pertanyaan terbuka, dimana dalam kuestioner tersebut terdapat 2 butir pertanyaan yang masing-masing mewakili variabel customer experience dan customer satisfaction. Model penelitian terdapat dalam Gambar 1.

\begin{tabular}{|l|l|}
\hline \multicolumn{1}{|c|}{\begin{tabular}{|l|} 
Customer Experience \\
$(\mathbf{1})$
\end{tabular}} \\
\hline $\begin{array}{l}\text { 1. Environtment } \\
\text { 2. Convenience } \\
\text { 3. Competence }\end{array}$ \\
\hline
\end{tabular}

Gambar 1. Model Penelitian

\section{Populasi dan Sampel}

Populasi dalam penelitian ini adalah pasien atau keluarga pasien di Instalasi Rawat Inap Rumah Sakit Immanuel. Adapun sampel dari penelitian ini yaitu pengguna jasa rawat inap Rumah Sakit Immanuel kelas VIP periode November 2019 - Maret 2020. Dalam pengambilan sampel penelitian ini, peneliti menggunakan rumus Slovin dengan tingkat kepercayaan 95\% dan tingkat error $5 \%$.

$$
\boldsymbol{n}=\frac{\mathbf{N}}{\mathbf{1}+\mathbf{N}(e)^{2}}
$$

Keterangan:

$$
\begin{array}{rlll}
\mathrm{n} \quad= & \text { Ukuran sampel } \\
\mathrm{N} \quad= & \text { Jumlah populasi } \\
\mathrm{e} \quad & \text { Presentase kesalahan yang ditolerir } \\
& \text { dalam pengambilan } & \text { sampel } \\
& \text { menggunakan } \mathrm{e}=5 \%(0,05)
\end{array}
$$

Berdasarkan perhitungan tersebut didapat sampel (n) sebanyak 169,78 dibulatkan menjadi 170 pasien rawat inap pasien Kelas VIP.

\section{HASIL DAN PEMBAHASAN}

Uji validitas kuesioner dengan menggunakan nilai koefisien korelasi product moment membuktikan bahwa dari 12 item pertanyaan yang digunakan, semua item pertanyan adalah valid, karena $r$ hitung $>r$ tabel $(0,30)$, dan nilai cronbach alfa adalah sebesar 0,914 dan lebih besar dari 0,6, sehingga dapat disimpulkan bahwa kuesioner penelitian ini adalah reliabel.

Karakteristik responden terdiri dari usia, jenis kelamin, kriteria responden, kota domisili, pendidikan terakhir, pekerjaan, dan kelas ruang rawat inap yang digunakan. Langkah-langkah analisis data meliputi uji asumsi klasik yang terdiri dari uji normalitas dengan menggunakan uji KolmogorovSmirnov menggunakan software IBM SPSS 22, dimana uji dilakukan untuk menguji apakah data terdistribusi normal, dengan taraf signifikansi < 0,05 . Selanjutnya dilakukan uji heteroskedastisitas, uji multikolinearitas, uji multikolinearitas, uji autokorelasi, uji parsial (t-test) berdasarkan nilai signifikansi, uji simultan (F-test) berdasarkan nilai signifikansi, uji hipotesis, analisis koefisien korelasi dan analisis koefisien determinasi.

Berdasarkan analisis deskriptif data dari indikator-indikator variabel yang terdapat dalam kuesioner penelitian yang disebarkan kepada 170 responden didapat hasil $83,5 \%$ responden menyatakan setuju bahwa dekorasi ruangan rawat inap tertata rapi, 14,1\% menyatakan sangat setuju dan 2,4\% berpendapat biasa saja, 68,2\% responden menyatakan setuju petugas kesehatan memberikan rasa nyaman, 31,8\% menyatakan sangat setuju, $77,1 \%$ responden menyatakan setuju bahwa petugas mengenal baik pasien, $21,8 \%$ menyatakan sangat setuju, dan 1,2\% berpendapat biasa saja, 60,6\% responden menyatakan setuju bahwa perawat terampil dalam merawat pasien, $28,2 \%$ menyatakan sangat setuju, 11,2\% responden berpendapat biasa saja, 73,5\% responden menyatakan setuju bahwa dokter dapat memberikan informasi diagnosa penyakit dengan jelas, $14,7 \%$ berpendapat biasa saja, $10,6 \%$ responden menyatakan sangat setuju, 1,2\% menyatakan tidak setuju, 68,2\% responden setuju petugas kesehatan dapat diandalkan, 18,2\% menyatakan sangat setuju, 11,8\% berpendapat biasa saja, 1,8\% menyatakan tidak setuju, 60\% responden menyatakan puas terhadap kesigapan perawat selama perawatan, 38,2\% menyatakan sangat puas,1,8\% berpendapat biasa saja, 56,5\% responden menyatakan puas terhadap kesigapan dokter dalam menangani pasien, 35,3\% menyatakan sangat puas, 7,6\% berpendapat biasa saja, $60,6 \%$ responden menyatakan puas terhadap interaksi petugas kesehatan dengan pasien selama 
perawatan, 32,9\% menyatakan sangat puas, 6,5\% berpendapat biasa saja, $74,7 \%$ responden menyatakan puas terhadap kecepatanan layanan petugas pendaftaran, $23,5 \%$ menyatakan sangat puas, $1,8 \%$ berpendapat biasa saja, $61,8 \%$ responden menyatakan puas terhadap kemudahan proses pendaftaran, 20,6\% berpendapat biasa saja, 17,6\% menyatakan sangat puas, 69,4\% responden menyatakan puas terhadap penjelasan petugas billing rawat inap dalam memberikan informasi tarif biaya perawatan, $16,5 \%$ berpendapat biasa saja, 12,4\% menyatakan sangat puas dan 1,8\% menyatakan tidak puas.

\section{Uji Normalitas}

$\begin{array}{rcr}\text { Setelah } & \text { dilakukan } & \text { uji normalitas } \\ \text { menggunakan } & \text { Uji } & \text { Kolmogorov-Smirnov }\end{array}$
menggunakan IBM SPSS 22 ternyata didapat data tidak terdistribusi normal (signifikansi $<0,05$ ). Oleh karena itu supaya didapat data terdistribusi normal tanpa menggunakan transformasi. Penulis menggunakan metode Monte Carlo, dan didapat hasil seperti pada Tabel 1.

Tabel 1. Hasil Uji Normalitas Kolmogorof-Smirnov

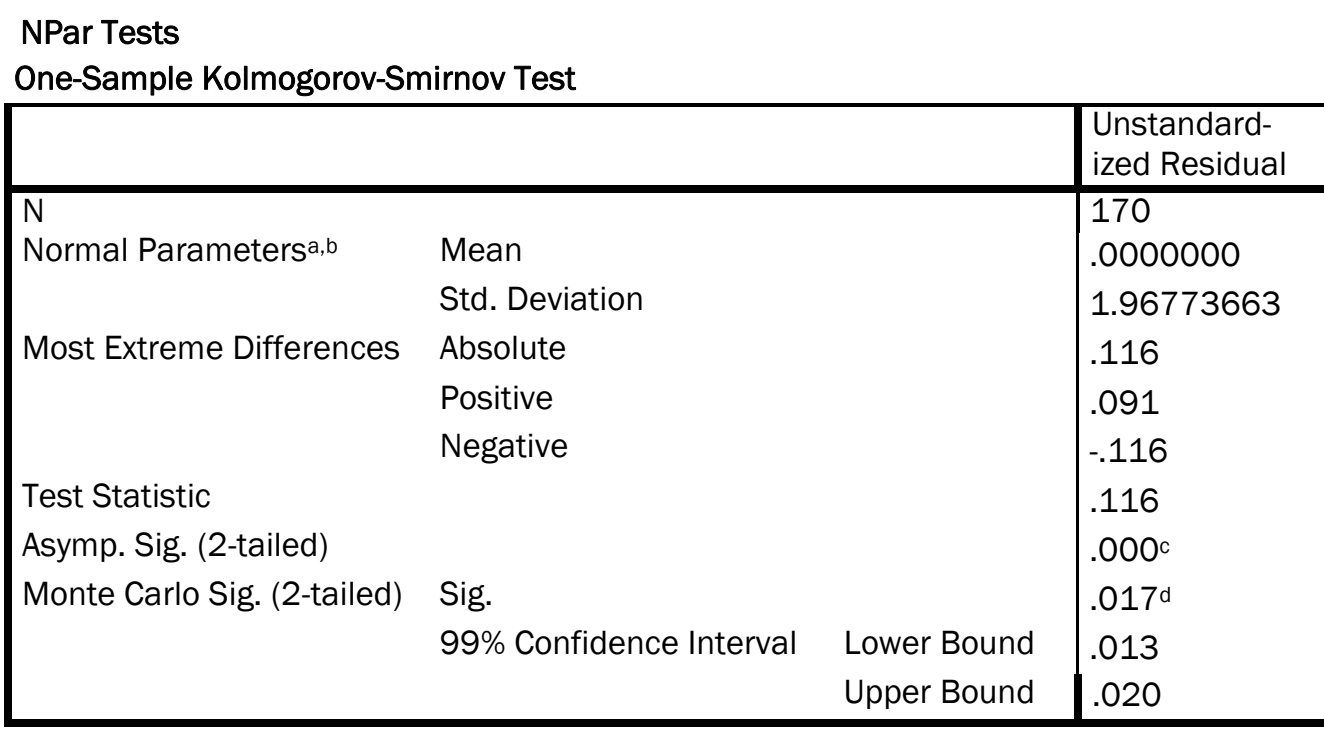

a. Test distribution is Normal.

b. Calculated from data.

c. Lilliefors Significance Correction.

d. Based on 10000 sampled tables with starting seed 2000000.

Berdasarkan hasil dalam tabel 1 tersebut, dimana nilai signifikansi (sig) sebesar 0,17 maka dapat disimpulkan bahwa model regresi berdistribusi normal.

\section{Uji Heteroskedastisitas}

Didapat titik-titik menyebar di atas dan dibawah angka 0 pada sumbu $Y$, sehingga dapat dsimpulkan tidak terjadi gejala heteroskedastisitas.

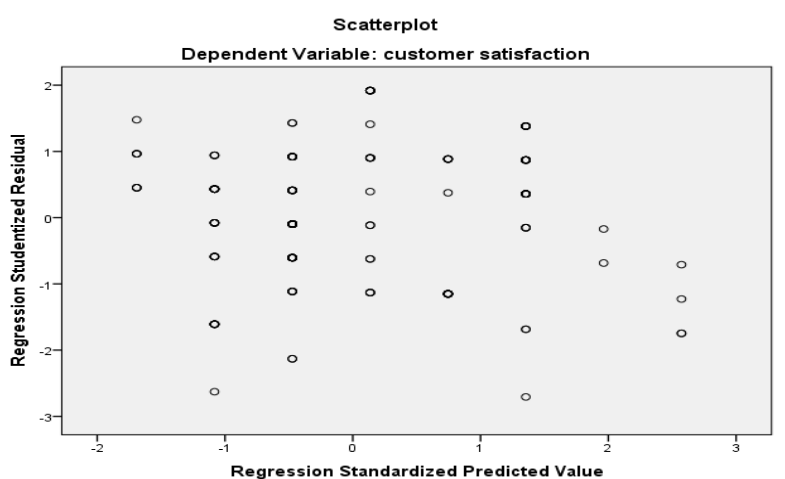

Gambar 2. Scaterplot Dependent Variable: Customer Satisfaction 


\section{Uji Multikolinearitas}

Ghozali [3] menyatakan cara mengetahui ada tidaknya gejala multikolinearitas dengan melihat nilai (VIF) dan tolerance dengan ketentuan jika nilai VIF kurang dari 10 (VIF < 10,00 dan tolerance lebih dari 0,1 (tolerance $>0,100$ ) maka dinyatakan tidak terjadi gejala multikolinearitas.

\section{Uji Autokorelasi}

Menurut Imam Ghozali [3], tidak terjadi gejala autokorelasi jika nilai tabel Durbin Watson terletak antara du sampai dengan (4-du). Tabel Durbin Watson adalah tabel pembanding dalam uji autokorelasi, dimana uji Durbin Watson adalah sebuat test yang digunakan untuk mendeteksi terjadinya autokorelasi pada nilai residual (prediction errors) dari sebuah analisis regresi.

Tabel 2. Hasil Uji Autokorelasi

Model Summary ${ }^{\mathrm{b}}$
\begin{tabular}{|l|l|l|l|l|l|}
\hline Model & $\mathrm{R}$ & R Square & $\begin{array}{l}\text { Adjusted } \\
\text { Square }\end{array}$ & $\begin{array}{l}\text { Std. Error of } \\
\text { the Estimate }\end{array}$ & Durbin-Watson \\
\hline 1 & $.654^{\mathrm{a}}$ & .427 & .424 & 1.974 & 1.968 \\
\hline
\end{tabular}

a. Predictors: (Constant), customer experience

b. Dependent Variable: customer satisfaction

Nilai du dicari pada distribusi nilai tabel Durbin Watson berdasarkan $\mathrm{k}(2)$ dan $\mathrm{N}(170)$ dengan signifikansi $5 \%$, didapatkan hasil du < durbin watson $<4-$ du atau 1,76093 < 1,968 < 2,23907. Karena nilai durbin watson terletak diantara du dan 4du maka disimpulkan bahwa tidak ada gejala autokorelasi.

\section{Uji Parsial (t-test) Berdasarkan Nilai Signifikansi}

Uji parsial (t - test) adalah uji pengaruh variabel $X$ secara sendiri-sendiri terhadap variabel $Y$. Menurut Imam Ghozali [3] jika nilai sig < 0,05maka ini berarti variabel independen $(X)$ secara parsial berpengaruh terhadap variabel dependen $(\mathrm{Y})$.

Tabel 3. Hasil Uji Parsial (t-test) Berdasarkan Nilai Signifikansi

\begin{tabular}{|c|c|c|c|c|c|c|c|c|}
\hline \multicolumn{9}{|c|}{ Coefficients $^{a}$} \\
\hline \multirow{2}{*}{\multicolumn{2}{|c|}{ Model }} & \multicolumn{2}{|c|}{$\begin{array}{l}\text { Unstandardized } \\
\text { Coefficients }\end{array}$} & \multirow{2}{*}{$\begin{array}{l}\text { Standardized } \\
\text { Coefficients } \\
\text { Beta }\end{array}$} & \multirow[b]{2}{*}{$\mathrm{t}$} & \multirow[b]{2}{*}{ Sig. } & \multicolumn{2}{|c|}{ Collinearity Statistics } \\
\hline & & $B$ & Std. Error & & & & Tolerance & VIF \\
\hline \multirow[t]{2}{*}{1} & (Constant) & -.667 & 2.296 & & -.291 & .772 & & \\
\hline & $\begin{array}{l}\text { customer } \\
\text { experience }\end{array}$ & 1.036 & .092 & .654 & 11.200 & .000 & 1.000 & 1.000 \\
\hline
\end{tabular}

a. Dependent Variable: customer satisfaction

Berdasarkan tabel 5 diatas didapatkan hasil signifikansi variabel $X$ sebesar 0,000 (nilai sig. <0.05). Ini berarti variabel customer experience $(X)$ berpengaruh terhadap customer satisfaction $(\mathrm{Y})$.

\section{Uji Simultan (F-test) Berdasarkan Nilai Signifikansi}

Menurut Iman Ghazali [3], jika nilai sig. < 0,05 maka artinya variabel independen $(X)$ secara simultan berpengaruh terhadap variabel dependen $(\mathrm{Y})$. 
Tabel 4. Hasil Uji Simultan (F-test) Berdasarkan Nilai Signifikansi

\begin{tabular}{|l|l|l|l|l|l|l|}
\hline \multicolumn{2}{|l|}{ ANOVA $^{\text {a }} \begin{array}{l}\text { Sum } \\
\text { Model }\end{array}$} & Squares & of & Mean Square & F & Sig. \\
\hline \multirow{2}{*}{1} & Regression & 488.628 & 1 & 488.628 & 125.449 & $.000^{\mathrm{b}}$ \\
\cline { 2 - 8 } & Residual & 654.366 & 168 & 3.895 & & \\
\cline { 2 - 8 } & Total & 1142.994 & 169 & & & \\
\hline
\end{tabular}

a. Dependent Variable: customer satisfaction

b. Predictors: (Constant), customer experience

\begin{tabular}{|l|l|l|l|l|l|}
\hline \multicolumn{5}{|l|}{ Model Summaryb } \\
\hline Model & $\mathrm{R}$ & R Square & $\begin{array}{l}\text { Adjusted } \\
\text { Square }\end{array}$ & $\begin{array}{l}\text { Std. Error of the } \\
\text { Estimate }\end{array}$ & Durbin-Watson \\
\hline 1 & $.654^{\mathrm{a}}$ & .427 & .424 & 1.974 & 1.968 \\
\hline
\end{tabular}

a. Predictors: (Constant), customer experience

b. Dependent Variable: customer satisfaction

Berdasarkan tabel 6 diatas dapat disimpulkan bahwa variabel $X$ secara simultan berpengaruh terhadap variabel Y. Besarnya prosentase (\%) pengaruh yang diberikan variabel $X$ secara parsial maupun simultan terhadap variabel $\mathrm{Y}$, berdasarkan tabel diatas adalah sebesar $42,7 \%$.

\section{Analisis Koefisien Korelasi Pearson}

Dari tabel 7 dibawah didapat hasil bahwa nilai korelasi variabel customer experience $(\mathrm{X})$ terhadap variabel customer satisfaction $(\mathrm{Y})$ memiliki derajat hubungan yang kuat dan bentuk hubungan positif (dimana jika nilai Pearson Correlation 0,60 0,80 korelasi adalah kuat), ini berarti semakin tinggi customer experience semakin tinggi pula customer satisfaction.

Tabel 5. Analisis Koefisien Korelasi Pearson

\begin{tabular}{|l|l|l|l|}
\hline \multicolumn{2}{|l|}{ Correlations } & $\begin{array}{l}\text { customer expe- } \\
\text { rience }\end{array}$ & customer satisfaction \\
\hline \multirow{2}{*}{ customer experience } & Pearson Correlation & 1 & $.654^{* *}$ \\
\cline { 2 - 4 } & Sig. (2-tailed) & & .000 \\
\cline { 2 - 4 } & $\mathrm{N}$ & 170 & 170 \\
\hline \multirow{3}{*}{ customer satisfaction } & Pearson Correlation & $.654^{* *}$ & 1 \\
\cline { 2 - 5 } & Sig. (2-tailed) & .000 & 170 \\
\cline { 2 - 4 } & $\mathrm{N}$ & 170 & 170 \\
\hline
\end{tabular}

** Correlation is significant at the 0.01 level (2-tailed). 


\section{Analisi Koefisien Determinasi}

Tabel 6. Tabel Analisis Koefisien Determinasi

\begin{tabular}{|l|l|l|l|l|}
\hline \multicolumn{3}{|l|}{ Model Summary } \\
\hline Model & $\mathrm{R}$ & $\mathrm{R}$ Square & $\begin{array}{l}\text { Adjusted } \\
\text { Square }\end{array}$ & $\begin{array}{l}\text { Std. Error of } \\
\text { the Estimate }\end{array}$ \\
\hline 1 & $.654^{\mathrm{a}}$ & .427 & .424 & 1.974 \\
\hline \multicolumn{5}{|l}{ Predictors: (Constant), customer experience } \\
\hline
\end{tabular}

Berdasarkan hasil tabel 8 diatas didapatkan hasil $\mathrm{R}^{2}$ sebesar 0,427. Ini dapat diartikan bahwa nilai variabel independen $(X)$ dalam model regresi adalah sebesear $42,7 \%$ dimana ini berarti kontribusi pengaruh atau proporsi dari variabel independen (customer experience) adalah sebesar $42,7 \%$ terhadap customer satisfaction, dan sisanya yaitu sebesar $57,3 \%$ dipengaruhi oleh faktor lain yang tidak diteliti dalam penelitian ini.

\section{Uji Hipotesis}

Tabel 7. Tabel Uji Hipotesis

\begin{tabular}{|c|c|c|c|c|c|c|}
\hline \multicolumn{7}{|c|}{ Coefficients $^{a}$} \\
\hline \multirow{2}{*}{\multicolumn{2}{|c|}{ Model }} & \multicolumn{2}{|c|}{ Unstandardized Coefficients } & \multirow{2}{*}{$\begin{array}{l}\text { Standardized } \\
\text { Coefficients } \\
\text { Beta }\end{array}$} & \multirow[b]{2}{*}{$\mathrm{t}$} & \multirow[b]{2}{*}{ Sig. } \\
\hline & & $\mathrm{B}$ & Std. Error & & & \\
\hline \multirow[t]{2}{*}{1} & (Constant) & -.667 & 2.296 & & -.291 & .772 \\
\hline & customer experience & 1.036 & .092 & .654 & 11.200 & .000 \\
\hline
\end{tabular}

a. Dependent Variable: customer satisfaction

Santoso[13] mengemukakan bahwa pengujian data dan hipotesis dilakukan dengan membandingkan nilai probabilitas (nilai sig.) dengan tingkat error, yaitu jika nilai sig. $>0.05 \rightarrow \mathrm{H}_{0}$ diterima dan jika nilai sig. $<0.05 \rightarrow \mathrm{H}_{0}$ ditolak. Berdasarkan ketentuan tersebut maka dalam penelitian ini dapat dilihat bahwa besar nilai signifikansi variabel customer experience $(\mathrm{X})$ sebesar 0,000 $(<0,005)$, maka $\mathrm{H}_{1}$ diterima. Ini menggambarkan bahwa terdapat pengaruh positif (nilai konstan 1,036) customer experience terhadap customer satisfaction pada pasien rawat inap kelas VIP di Rumah Sakit Immanuel Bandung.

Dari hasil pengumpulan data dari 10 sampel responden yang diberikan kuesioner bersifat pertanyaan terbuka, dimana dalam kuesioner tersebut terdapat 2 butir pertanyaan yang masingmasing mewakili variabel customer experience dan customer satisfaction. Berdasarkan pertanyaan variable customer experience yaitu mengenai pengalaman yang paling menyenangkan / berkesan selama menjalani perawatan, responden berpendapat pengalaman yang paling berkesan adalah keramahan para staf, kemudahan dan kecepatan mulai dari pendaftaran, fasilitas yang memadai, area rumah sakit yang relatif luas, tidak terasa sempit dan tidak berliku-liku, ruang rawat yang luas, makanan yang enak. Sedangkan berdasarkan pertanyaan yang berhubungan dengan kepuasan konsumen yaitu faktor apa saja yang dapat memberikan kepuasan selama menjalani perawatan adalah pelayanan yang maksimal dan komunikasi dan sikap yang baik dari para staf, kecepatan dan ketepatan tindakan, ruang perawatan yang terang, nyaman serta luas, fasilitas yang lengkap, kecepatan dan kemudahan dalam proses pembayaran. Selain itu peneliti juga melakuka depth interview kepada pasien dan keluarga mengenai faktor-faktor yang berhubungan dengan pelayanan dan didapatkan informasi bahwa pasien atau keluarga pasien puas terhadap pelayanan di rawat inap dan pada umumnya pasien sudah pernah berobat atau dirawat di Rumah Sakit Immanuel. Alasan memilih Rumah Sakit Immanuel adalah selain karena lokasi, juga karena sudah merasa nyaman dan puas dengan pelayanan yang diberikan oleh perawat dan dokter. Akan tetapi masih ada ketidakpuasan pada saat pelayanan di Instalasi Gawat Darurat dalam hal lama menunggu untuk dilayani. 


\section{KESIMPULAN}

Berdasarkan hasil penelitian dapat ditarik kesimpulan bahwa adanya pengaruh yang positif customer experience terhadap customer satisfaction pada pasien rawat inap kelas VIP di Rumah Sakit Immanuel Bandung, hal ini dapat dilihat dari nilai $\mathrm{R}^{2}$ sebesar 0.427 atau sebesar $42,7 \%$ dan sisanya yaitu sebesar $57,3 \%$ dipengaruhi oleh faktor lain yang tidak diteliti dalam penelitian ini. Adapun aspek-aspek customer experience yang mempengaruhi kepuasan pada pasien rawat inap adalah dekorasi ruangan (environtment), petugas kesehatan memberikan rasa nyaman kepada pasien dan mengenal dan mengingat pasien dengan baik, keterampilan perawat dalam melakukan tindakan, kejelasan informasi diagnosa pasien yang diberikan oleh dokter, petugas dapat diandalkan dalam mengambil tindakan dalam memenuhi kebutuhan pasien, kecepatan, kemudahan, dan kenyamanan petugas dalam memberikan perawatan, kesigapan dokter dalam menangani pasien, interaksi dengan petugas kesehatan dalam perawatan yang berhubungan dengan proses penyembuhan, kecepatan layanan petugas, prosedur administrasi / pendaftaran pasien dimulai masuk rumah sakit selama perawatan berlangsung sampai keluar dari rumah sakit dan akurasi penagihan/ billing perawatan. Faktor-faktor ini dapat diidentifikasi sebagai unsur-unsur titik kontak customer experience, yaitu titik-titik kritis dimana konsumen merasakan jasa/layanan rumah sakit.

Peneliti memberikan saran dari hasil penelitian yaitu bagi penelitian selanjutnya perlu diteliti atau ditambahkan variabel independen yang lain selain customer experience yang berpengaruh secara positif terhadap customer satisfaction. Selain itu berdasarkan hasil penelitian didapatkan bahwa ada pengaruh positif customer experience terhadap customer satisfaction, maka rumah sakit perlu lebih memperhatikan keunggulan bersaing ditinjau dari faktor-faktor environtment, convenience, competence, performance, dan realibility karena terbukti berpengaruh terhadap kepuasan konsumen dalam hal ini pasien rawat inap.

\section{DAFTAR PUSTAKA}

[1] S. Herlambang, Customer Service Rumah Sakit dan Jasa Kesehatan: Cara Sukses Melayani Pelanggan Di Dunia Kesehatan, Yogyakarta: Gosyen Publishing, 2018.

[2] F. Tjiptono, Service Management: Mewujudkan Layanan Prima, vol. 3, Yogyakarta, 2017.
[3] I. Ghozali, Aplikasi Analisis Multivariate Dengan Program SPSS, Semarang: Badan Penerbit Universitas Dipenogoro, 2011.

[4] D. \&. I. J. Shaw, Building Great Customer Experience, New York: MacMillan. Smith,S, 2002.

[5] E. Andajani, "Understanding Customer Experience Management In Retailing," in 2nd Global on Business and Social Science-2015, Bali-Indonesia, 2015.

[6] F. Lemke, C. M and W. H, "What Makes A Great Customer Experience," in Cranfield Customer Management Forum, 2006.

[7] S. Kim, j. Knutson and J. Beck, Development and Testing of the Customer Experience Index (CEI)," in Managing Service, vol. 21, 2011, pp. 112-132.

[8] P. J. II and J. Gilmore, "Differentiating Hospitality Operations Via Experiences," in Cornell Hotel and Restaurant Administration Quaterly, vol. 43, 2002, pp. 87-96.

[9] A. Stein and B. Ramaseshan, Towards The Identification Of Customer Experience Touch Point Elements," Journal Of Retailing and Customer Services, vol. 30(C), pp. 8-19, 2016.

[10] P. Kotler and K. L. Keller, Marketing Management, 15 ed., Pearson Education, Inc, 2016.

[11] M. Eisenbeiss, M. Corneliben, K. Backhaus and H. D. W, Nonlinear and Asymetric returns On Customer Satisfactiob: Do They Vary Across Situations And Consumers?,Journal Of The Academy Of Marketing Science, vol. 42 (3), pp. 242-263, 2014.

[12] G. Hult, P. N. Sharma, F. V. Morgeson and Y. Zhang, Antecendents and Consequences Of Customer Satisfaction: Do They Differ Across Online And Offline Purchases?, Journal of Retailing, vol. 95(1), pp. 10-23, 2019.

[13] S. Santoso, SPSS Versi 11,5: Mengolah Data Statistik Secara Profesional, Jakarta: PT. Elex Media Komputindo, 2001. 